IJBPAS, December, Special Issue, 2021, 10(12): 353-359

ISSN: 2277-4998

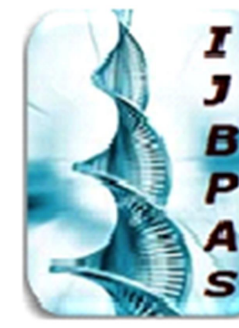

International Journal of Biology, Pharmacy and Allied Sciences (IJBPAS)

'A Bridgs Betusen Caboratory and Qandor'

Www.ibpas.com

\title{
PHARMACEUTICAL AND ANALYTICAL STUDY OF A POTENT FORMULATION GUDUCHI SATVA
}

\section{LEKSHMIPRIYA $S^{1}$, M R PANDYA ${ }^{2}$, BIJAL PRAJAPATI ${ }^{3}$ AND SNIGHDA DAS MANDAL ${ }^{4}$}

1: PhD Scholar, Department of Rasashastra \& Bhaishajya Kalpana, Parul University

2: PhD Guide, Department of Rasashastra \& Bhaishajya Kalpana, Parul University

3: HOD \& Co-guide, Department of Pharmaceutics, Parul Institute of Pharmacy, Parul University

4: HOD, Department of Pharmacology. Parul Institute of Pharmacy and Research, Parul University

*Corresponding Author: Dr Lekshmipriya S; E Mail: ponni777@gmail.com

Received $9^{\text {th }}$ May 2021; Revised $10^{\text {th }}$ July 2021; Accepted $29^{\text {th }}$ Aug. 2021; Available online $15^{\text {th }}$ Dec. 2021

https://doi.org/10.31032/IJBPAS/2021/10.12.1031

ABSTRACT

Guduchi is a widely known drug with immense potential benefits. There are mainly two kinds of Guduchi mentioned in Ayurveda classics. The Guduchi species considered for the present study is Tinospora crispa L. Hook. Guduchi satva is a well-known Ayurvedic formulation explained in Yogaratnakar/ Rajayakshma Chikitsa. The method of preparation is clearly explained in Ayurveda Sara Sangraha. As per the reference it is mainly used for treating Teevra tapa (Pyrexia), jwara (Fever), raktapitta (bleeding disorders), rakta pradara (Uterine haemorrhage) etc. The dose explained in classics is 4ratti to 1 Masha (500mg-1g). In the current study Guduchi satva will be prepared as per the Ayurveda Sara Sangraha reference by collecting Guduchi (Tinospora crispa L. Hook) of Menispermaceae family. Then the Guduchi satva analytical evaluation will be performed as per API guidelines.

Key words: Guduchi, Tinospora crispa, Guduchi satva, Ayurveda Sara Sangraha 


\subsection{INTRODUCTION}

The concept behind Ayurveda is preventing unnecessary suffering and living a long healthy life. Ayurveda involves the use of natural means such as diet, herbs, spices, minerals, exercise, meditation, yoga, mental hygiene, sounds, smells and mechano-procedures to eliminate the root cause of the disease by restoring balance, at the same time create a healthy life-style to prevent the reoccurrence of imbalance [1]. The Indian Ayurvedic system has included herbals as one of its most powerful healing ingredients, which are recorded in the literature such as Vedas and Samhitas. Based on the material of origin, Ayurvedic medicines are divided into three classes, namely herbal, mineral and animal. Among this, herbal formulation has gained great importance and rising global attention recently. This scenario is obvious as major increase in the herbal formulation usage has been observed throughout the last few years in developed world, where market expansion occurred in European countries and USA [2]. The World Health Organization (WHO) estimates that $80 \%$ of the word's inhabitants still rely mainly on traditional medicines for their health care [3]. In the prevailing study the drug considered from Tinospora species is Tinospora crispa L.Hook. The potent Ayurveda formulation Guduchi satva is prepared out of the Tinospora crispa $L$. Hook. It is very well detailed in the pharmaceutical aspect. Then the prepared Guduchi satva was subjected to analysis and anticipatory interpretation has been proven out in the current study.

\subsection{MATERIALS AND METHODS}

The study comprises of two parts:

2.1 Pharmaceutical Study

2.2 Analytical Study

\subsection{Pharmaceutical Study:}

a) Procurement of Raw material Tinospora crispa

b) Authentication of the drug

c) Preparation of Guduchi satva

\section{a. Procurement of raw material:}

The correct identification of herbal plant is the first step in quality control as recommended by WHO. The fresh stems of Tinospora crispa for the current study has been collected from Tirumala, Trivandrum, Kerala [4].

\section{b. Authentication of the drug:}

The stem along with the leaves was sent to FRLHT, Bangalore for identification and authentication of the drug. It has been authenticated as Tinospora crispa by $\mathrm{Dr}$ Noorunnisa beegum S, Associate Professor, Centre for Conservation of Natural Resources, TDU [4].

\section{c. Preparation of Guduchi Satva:}


Guduchi stem approximately $2.5-3.0 \mathrm{~cm}$ diameter and having dark brown colour with evident tubercles were collected in the month of December. The physical impurities were removed \& washed thoroughly with water. The outer husk was peeled off and it has been cut into small pieces. It was crushed in a ulukhala yantra and soaked in 21 parts of water in a stainless-steel vessel [5]. The whole mixture was macerated rigorously to facilitate the starch into the liquid. The remnant fibrous \& woody parts were removed, the vessel is placed undisturbed for $12 \mathrm{hrs}$ and the supernatant water is carefully filtered out through a four folded cotton cloth. The starch sediment at the base was washed with little quantity water, dried in tray dryer, collected the sample and stored as Guduchi satva in airtight container.

\section{Observations:}

1. During the maceration the sliminess was more in the water and gradually it reduced

2. The water turned turbid and the colour of the liquid after straining with four folded cloth was greenish.

3. The remnant fibrous woods found to be floating over the surface of the water

\subsection{Analytical Profile of Guduchi satva}

The analytical profile of Guduchi satva prepared out of Tinospora crispa is done with the reference of PLIM guidelines [6]. The Analytical study has been carried out in Vasu Pharmaceuticals, Vadodara, Gujarat, India.

\section{The following are the analytical profile} data:

Physiochemical Studies: Physiochemical parameters like $\mathrm{pH}, \mathrm{LOD}$, total ash, acid insoluble ash and water soluble and alcohol soluble extractive values, total alkaloids, Heavy metal detection, Microbial limit tests, HPTLC, GCMS were determined as per PLIM guidelines

Phytochemical screenings: Preliminary qualitative phytochemical screening was carried out and revealed the presence of a wide range of phytoconstituents Alkaloid, Starch, Carbohydrates, Tannins \& Polyphenols, Flavonoids, Saponins \& Steroids. The HPTLC Fingerprinting analysis was carried out in Guduchi satva with solvent system i.e., Chloroform: Methanol (9:1 v/v) using CAMAG HPTLC system consisting of Linomat 5- Applicator. The chromatogram obtained was studied under $254 \mathrm{~nm}, 366 \mathrm{~nm}$ and 540nm after derivatization.

GCMS study was done to find out the bioactive compounds in Guduchi satva. It was carried out in SICART, Anand, Gujarat. The interpretations were done through PubChem \& Dr. Duke's Phytochemical and Ethnobotanical data base. 


\subsection{RESULTS}

Table 1: Preparation of Guduchi Satva

\begin{tabular}{|c|c|c|}
\hline $\begin{array}{c}\text { Quantity of Guduchi while } \\
\text { collected }\end{array}$ & $3.716 \mathrm{~kg}$ & Loss in Kg/gm \\
\hline $\begin{array}{c}\text { After } 3 \text { days the quantity of } \\
\text { Guduchi }\end{array}$ & $2.830 \mathrm{Kg}$ & $\mathbf{- 8 8 6 g m}$ \\
\hline $\begin{array}{c}\text { After removing the foreign } \\
\text { matter }\end{array}$ & $2.016 \mathrm{Kg}$ & $\mathbf{- 8 1 4 g m}$ \\
\hline $\begin{array}{c}\text { After peeling off the outer } \\
\text { covering }\end{array}$ & $1.280 \mathrm{Kg}$ & $\mathbf{- 7 3 6 g m}$ \\
\hline $\begin{array}{c}\text { After making into pieces \& } \\
\text { crushing }\end{array}$ & $1.240 \mathrm{Kg}$ & $-40 \mathrm{gm}$ \\
\hline Quantity of water added & $26.04 l i t r e s$ & - \\
\hline Yield of Guduchi satva & $29 \mathrm{gms}$ ie $2.4 \%$ only & - \\
\hline
\end{tabular}

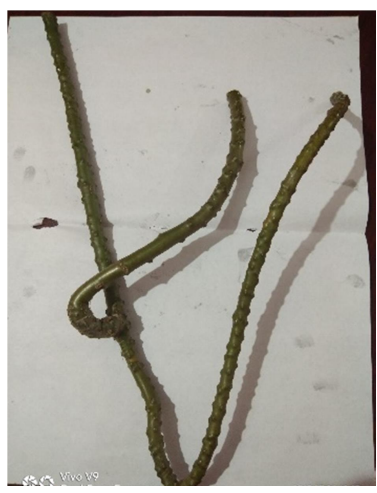

Fig 01: Tinospora crispa

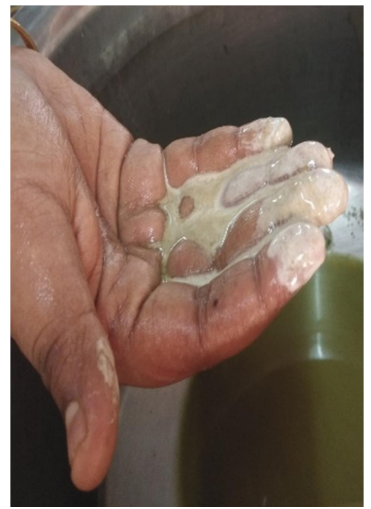

Fig 05: Guduchi satva before drying

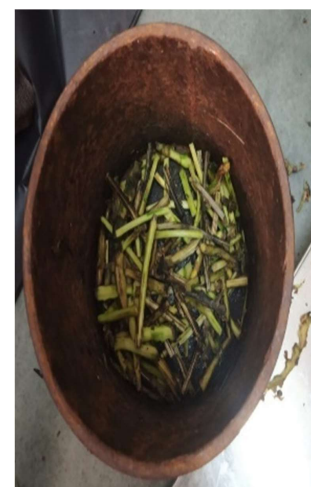

Fig 02: crushed Tinospora crispa

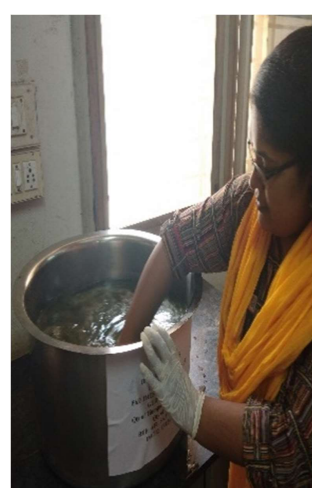

Fig 03: crushed Tinospora crispa with water

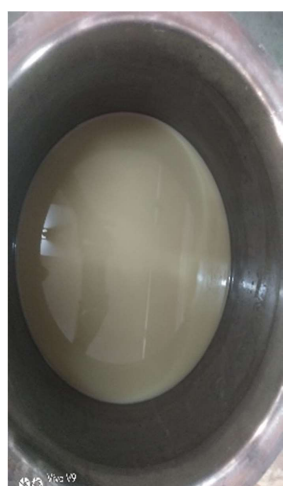

Fig 04: Guduchi satva at the bottom of vessel

Table 2: Analytical Profile of Guduchi satva with anticipatory interpretation

\begin{tabular}{|c|c|c|c|}
\hline 1 & pH & 4.68 & Quantitative indication of acidic nature of the drug \\
\hline 2 & Loss on Drying & $6.31 \%$ & $\begin{array}{c}\text { Indicates the loss of amount of water \& other volatile impurities } \\
\text { present in the sample }\end{array}$ \\
\hline 3 & Total Ash & $4.36 \%$ & It indicates the purity of the drug \\
\hline 4 & Total Solid Content & $\mathbf{9 3 . 6 9 \%}$ & Constitutes both suspended and dissolved solids \\
\hline 5 & Water Soluble Extractive & $7.14 \%$ & Indicates the water-soluble constituents in the trial drug \\
\hline 6 & Alcohol Soluble Extractive & $\mathbf{3 . 1 4 \%}$ & Indicates the Alcohol soluble constituents in the trial drug \\
\hline 7 & Alkaloids (Gravimetry) & $\mathbf{0 . 6 3 \%}$ & $\begin{array}{c}\text { The possible alkaloids are Tinosporine, Magnoflorine, Berberine, } \\
\text { Choline, Jatrorrhizine }\end{array}$ \\
\hline
\end{tabular}


Table 3: Phytoconstituent Qualitative assay of Guduchi satva

\begin{tabular}{|c|c|c|}
\hline 1 & Starch \& Carbohydrates & ++ \\
\hline 2 & Alkaloids & ++ \\
\hline 3 & Steroids & + \\
\hline 4 & $\begin{array}{c}\text { Glycosides, Saponins, Tannins, Flavonoids, } \\
\text { Phenols, Proteins }\end{array}$ & Absent \\
\hline
\end{tabular}

Table 4: heavy Metal Analysis (AAS) \& Microbial limit Tests

\begin{tabular}{|c|c|c|}
\hline \multicolumn{3}{|c|}{ Heavy Metal Analysis of Guduchi satva } \\
\hline 1 & Lead and cadmium & Absent \\
\hline 2 & Arsenic & $0.18 \mathrm{ppm}$ \\
\hline 3 & Mercury & $\mathbf{0 . 6 0 p p m}$ \\
\hline \multicolumn{3}{|c|}{ Microbial Limit Tests of Guduchi satva } \\
\hline 1 & Total microbialcount plate count & $\mathbf{2 8 8 9} \mathrm{cfu} / \mathrm{g}$ \\
\hline 2 & Total Yeast \& Mould count & $\mathbf{9 3 2} \mathrm{cfu} / \mathrm{g}$ \\
\hline 3 & E. coli, Salmonella, S, Aureus, P. aeruginosa & Absent \\
\hline
\end{tabular}

Table 5: HPTLC fingerprint analysis report

\begin{tabular}{|c|c|c|}
\hline Visualization & No: of spots & Rf value \\
\hline $254 \mathrm{~nm}$ & 1 & 0.24 \\
\hline $366 \mathrm{~nm}$ & 5 & $\mathbf{0 . 1 3 , 0 . 2 4 , 0 . 5 5 , 0 . 6 1 , 0 . 7 4}$ \\
\hline $540 \mathrm{~nm}$ & 7 & $\mathbf{0 . 2 4 , 0 . 3 1 , 0 . 3 7 , 0 . 5 5 , 0 . 7 3 , 0 . 8 4 , 0 . 8 7}$ \\
\hline
\end{tabular}

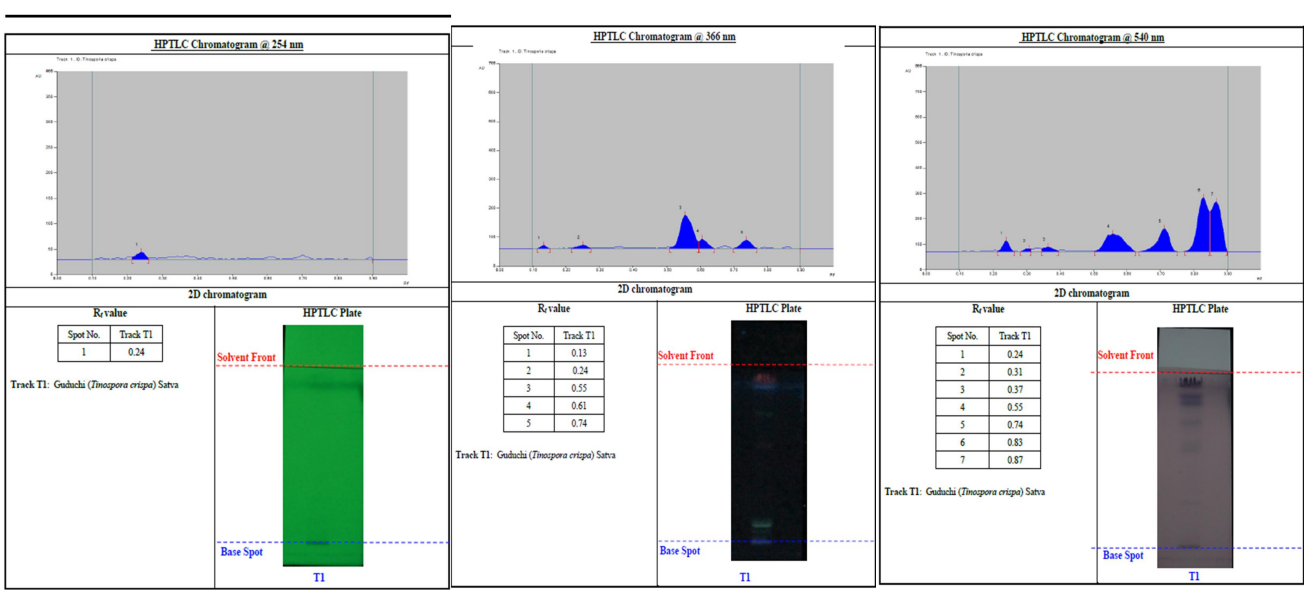

Fig 08:@254nm

Fig 09:@366 nm

Fig $10 @ 540 \mathrm{~nm}$

Table 6: GCMS Results with anticipatory interpretations

\begin{tabular}{|c|c|c|c|}
\hline S. No. & Name of compound & Nature of compound & Activity \\
\hline 1 & $\begin{array}{c}\text { Eicosanoic Acid (Arachidonic } \\
\text { Acid) }\end{array}$ & $\begin{array}{l}\text { Plant Metabolite, Fatty } \\
\text { acid ester }\end{array}$ & $\begin{array}{c}\text { Antipyretic, Anti-inflammatory, Anti } \\
\text { Allergic, Anti Cancerous, Anti-Hypertensive }\end{array}$ \\
\hline 2 & Pentadeconoic Acid & $\begin{array}{l}\text { Palmitic Acid, Methyl } \\
\text { Ester }\end{array}$ & Antioxidant \\
\hline 3 & N-hexadecenoic Acid & Palmitic Acid & Antioxidant \\
\hline 4 & Octadecanoic Acid & Fatty acid Ester & Antioxidant,Antiviral \\
\hline 5 & Nonadecanoic Acid & Fatty acid Ester & Antioxidant \& in Colorectal CA \\
\hline 6 & Dodecanoic Acid (Lauric Acid) & Fatty acid Ester & $\begin{array}{l}\text { Anti hypercholesteremia } \\
\text { Anti atherosclerosis }\end{array}$ \\
\hline 7 & $\begin{array}{c}\text { Tridecanoic Acid (Myristic } \\
\text { Acid) }\end{array}$ & Fatty Acid Ester & Increases HDL level \\
\hline 8 & Heptadecanoic Acid & Margaric Acid & Antioxidant \\
\hline 9 & Pyrrolidine & Natural Alkaloid & $\begin{array}{c}\text { Antioxidant, Antipyretic, Anti- } \\
\text { inflammatory, Anti-mycobacterial, } \\
\text { Antiulcer, Anti-tuberculosis and herbicidal } \\
\text { activity }\end{array}$ \\
\hline
\end{tabular}




\subsection{DISCUSSION}

In the current study the Guduchi satva is prepared out of Tinospora crispa variety and the yield obtained was $2.4 \%$.The various article data also shows that the yield of Guduchi satva may vary with season and size of the stem. There are different methods explained for the preparation of Guduchi satva. The prevailing study focussed on the reference available in Ayurveda Formulary of India.If we compare Tinospora cordifolia and Tinospora crispa in the preparation of Guduchi satva during preparation more sliminess was observed in water with Tinospora crispa.Then the prepared Guduchi satva was subjected to analytical studies. The physiochemical analysis results with interpretations have been mentioned in Table No:2 of the current article. The qualitative phytoconstituent assay revealed the presence of starch, carbohydrate, alkaloids and steroids. So, the Guduchi satva prepared out of Tinospora crispa will have anti-oxidant, anti-pyretic, anti-inflammatory etc. properties. The HPTLC and GCMS reports were well discussed in Table 05 \& Table 06 of existing article. The GCMS reports vividly throws light into the major activities exhibited by the Tinospora crispa satva.

\subsection{CONCLUSION}

The current research was a sincere attempt to find out the yield of Guduchi satva with Tinospora crispa and established an analytical profile of Guduchi satva prepared out of the selected Tinospora species. Further research can be carried out in Guduchi satva prepared with Tinospora crispa in connection with the found activities. Also, Preclinical and Clinical studies can be initiated with this preliminary data.

\subsection{REFERENCES}

[1] Subramani Parasuraman et al Polyherbal Formulation-Concept of Ayurveda Pharmacogn Review 2014 Jul-Dec; 8(16): 73-80

[2] Kamboj VP. Herbal medicine. Curr Sci. 2000; 78:35-51. [Google Scholar]

[3] Mathew L, Babu S. Phytotherapy in India: Transition of tradition to technology. Curr Bot. 2011; 2:1722. [Google Scholar]

[4] S Lekshmipriya et al, Analytical Profile of an Unparalleled Drug Tinospora crispa W.R. T Guduchi, Journal of Pharmaceutical Research International, 33(49B): 195-203, 2021; Article no. JPRI.77006 ISSN: 2456-9119

[5] A.F.I Government of India, Ministry of Health and Family 
Welfare, 2003, Part I, (14:205) $2^{\text {nd }}$

edition.

[6] Pharmacopeial Standards for Ayurvedic Formulations, Central Council of Research in Ayurveda and siddha, Government of India, Ministry of Health and Family Welfare, The controller of publications, New Delhi, 1987. 